\title{
Bullying Of Educators By Educators: Incivility In Higher Education
}

Chula King, University of West Florida, USA

Chris Piotrowski, University of West Florida, USA

\begin{abstract}
Bullying of adults by adults appears to be a common experience in work, social, and even family life. Yet, historically, there has been limited empirical research on the nature of this prevalent and aberrant interpersonal style among personnel in higher education. This article presents a review of studies that reflect key issues on bullying and incivility of/by administrators, faculty, and staff in college and university settings. There is strong empirical evidence that depicts the adult bully as harboring pervasive psychopathological tendencies such as narcissism and Machiavellianism, with a propensity for exhibiting abusive, controlling, callous, condescending, domineering, coercive, and self-centered behaviors (see Piotrowski, 2015). Several hypothetical case vignettes of incivility/bullying incidents specific to the academe are offered to illustrate these tendencies, along with strategies to recognize, manage, and combat 'bullying' styles in interpersonal interactions in college/university settings. Official policy should designate higher education settings as a 'No Bully Zone'.
\end{abstract}

Key Words: Bullying; Incivility; Mobbing; Higher Education; Faculty; Support Staff; Administrators

\section{INTRODUCTION}

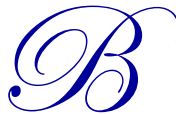

ullying is an abusive behavior that, undoubtedly, has had a long history and is quite pervasive in contemporary society. Yet researchers in this area have largely neglected the study of educational settings, which is a major work milieu in modern society where teachers, administrators, and staff interact in both professional and personal roles (Lester, 2013). Fortunately, emerging research on workplace bullying in educational settings has recently appeared in the literature, as teachers can become prime targets of incivility, retaliation, and harassment (Fox \& Stallworth, 2010). However, most studies have focused on primary school settings (e.g., Cemaloglu, 2011; Korkmaz \& Cemaloglu, 2010). Moreover, investigators have primarily examined instructor-to-instructor bullying (Gray \& Gardiner, 2013), although there has been a growing interest in the topic of harassment of teachers by administrators, parents, and students (Randel, 2008). One report of elementary and secondary school settings found that between $22 \%$ and $36 \%$ of teachers were bullied by parents; $15 \%$ were bullied by fellow teachers; and alarmingly, 25\% experienced bullying by educational administrators which included condescending criticism, intimidation, organizational isolation, and reduction of official responsibilities (Matsui, 2005). In a qualitative design, Blasé and Blasé (2002) explored the deleterious impact that mistreatment by principals can have on the mental health of teachers and on classroom instruction.

The aim of the current study is three-fold: a) to review emerging research on bullying and related incivility of adults by adults in higher education settings; b) to present hypothetical case vignettes of incivility/bullying incidents specific to the academe; and c) to offer potential strategies that show promise in recognizing and combating 'bullying' styles in interpersonal interactions in college/university settings. 


\section{RESEARCH ON BULLYING IN HIGHER EDUCATION}

Anecdotal reports and discussions of 'interpersonal bullying and incivility' experienced by college administrators, professors, and staff have recently appeared in the literature (Cassell, 2011; Lester, 2013). Actually this is not surprising given the top-down organizational structure of colleges and universities (Twale \& De Luca, 2008). Undoubtedly, the impact of incivility in academic settings can have onerous repercussions both for employees (in the form of humiliation, resentment, demoralization) and on the institutional climate (productivity, collegiality, faculty retention) (Raskauskas \& Skrabec, 2011). Sadly, in escalated form, groups of individuals (a.k.a. Mobbing) can conspire and coordinate attacks on a specific victim (Keim \& McDermott, 2010). In a phenomenological-qualitative design, Sedivy-Benton et al. (2014) reported on the reactions of female college faculty who experienced rather cruel treatment from several fellow faculty (mobbing); alarmingly, much of this bullying was condoned by administrators. Such abuse by supervisors in the academe has been noted in the literature (Thomas, 2010). At the same time, incidents of bullying in higher education can harbor infractions of discrimination that reflect a racial tone (see Frazier, 2011). In a novel approach, Settles and O'Connor (2014) reported on the propensity for incivility experienced by college instructors from fellow faculty at academic conferences, an extension of the professional workplace.

\section{Prevalence Statistics}

In a dissertation study, Mourssi-Alfash (2014) examined the relationship between workplace bullying and organizational justice among faculty and staff at a university in the Midwest. Based on data from 786 respondents, $35 \%$ confirmed that they had been bullied, with females reporting the highest incidence rate. Thomas (2005), in a study on bullying at a large university in the United Kingdom, found that $45 \%$ of support staff employees reported being bullied and $40 \%$ witnessed colleagues being bullied.

\section{ILLUSTRATIONS OF ADULT BULLYING SCENARIOS IN HIGHER EDUCATION SETTINGS}

Based on qualitative interviews of real-life bullying experiences by college personnel reported in the literature, and the experiences of the authors during their academic career, several hypothetical illustrative examples of adult bullying scenarios are summarized below (any resemblance to actual events, locales, or persons, living or dead, is entirely coincidental).

\section{Vignette \#1: Upper-level Administrator to Faculty and Graduate Students (The Intimidator)}

A seasoned professor and the provost were close friends at a university. Soon after the provost assumed his current position, his friend was appointed to a position overseeing the university's research efforts. As such he was responsible for reviewing research grant proposals, as well as graduate theses and dissertations. By nature, he was very insecure. On top of that, he had limited experience with publication standards. These two traits combined to create the Intimidator whose actions were characterized by verbal outbursts, a condescending style, and tedious critiques of submitted research manuscripts. His domineering approach and bullying escalated to the point where faculty advisors, department chairs, and deans had to employ 'intermediaries' in any communications with the Intimidator. His severe criticism of faculty research proposals and graduate theses and dissertations prompted an official meeting before the faculty senate, where he was uniformly rebuked for his harsh and unwarranted written and verbal attacks. Despite this obvious 'bullying' style, the provost dismissed all concerns and retained the Intimidator in his position. When he learned that the provost had accepted a position at a different university, the Intimidator immediately resigned his position. By that point, he had lost all credibility with the university community.

\section{Vignette \#2: Administrator to Administrator (The Coercer)}

He was a former faculty member who ascended to a position of authority in the administration by coercion. His arrogant and egocentric tendencies preyed on administrators with two different types of personalities. The first personality type was one where the administrator was equally arrogant and egocentric, but totally unprepared for the job at hand. The Coercer made these individuals believe that they could not perform their administrative tasks 
without total reliance on him. Over time, the Coercer took every advantage of the observed insecurities to demean the fellow administrators and exert his control over important decisions. The second personality type was one where the administrator harbored few insecurities, and garnered the general respect of peers and subordinates. The more unsuccessful the Coercer was at exerting his main weapon of coercion on this type of administrator, the more frustrated and insecure he became. Therefore, rather than direct attacks, the Coercer sought to demean his secure colleagues through indirect bullying, i.e., attempting to convince others to gang up on the administrators and launch attacks from multiple positions. In the end, the Coercer returned to faculty, but not without exerting significant harm on the institution and those around him.

\section{Vignette \#3: Administrator to Subordinate (The Flatterer and Manipulator)}

She was also a former faculty member who ascended to a position of authority in the administration. Unlike the Coercer, her weapons were flattery and manipulation. Her peers were mostly flattered; her subordinates were mostly manipulated. As one might imagine, the flattery worked well on the arrogant and egocentric peers. In some cases, these peers were made to believe that they could not function without the Flatterer, and therefore became totally dependent thereon. Those who suffered the most, however, were the subordinates who were manipulated, disrespected, and harassed. The Manipulator spent her days creating meaningless tasks for her subordinates to complete, and took every opportunity to demean their positions and accomplishments. Because her job function was marginal at best, the Manipulator's creation of the meaningless tasks was an attempt to provide the appearance of her relevance to the operation of the university. Any subordinate who attempted to 'escape' and find a job elsewhere at the university was severely reprimanded for not being loyal. In the end, the Flatterer and Manipulator returned to the faculty, but not without exerting significant harm on the institution and those around her.

\section{Vignette \#4: Faculty to Faculty (The Bully Extraordinaire)}

They were both in the same department, and by all accounts equal in rank and promise. Personality-wise, they were as different as two individuals could be. One was a former defensive football player who had a history of using his muscle to thwart the opponent. The other had never played any type of contact sport and generally got along with those around him with his non-aggressive behavior. Things went well until the two began dating the same student. This in and of itself was a challenge. However, the real problem surfaced when the football player became the Bully Extraordinaire. It began with general incivility between the two departmental colleagues, and quickly escalated as the Bully Extraordinaire took aim on his departmental colleague whom he viewed as the opponent. His tactics shifted from the physical weapons used in defensive football, to psychological tactics designed to destroy his opponent in the eyes of the 'prize', i.e., the female student. These psychological tactics involved harassment, stalking, and lie spreading. At one point, security was called in because of concerns over the personal safety of departmental colleagues. In the end, both colleagues lost when the female student graduated. However, this loss was not without cost to the non-aggressive departmental colleague who felt that his only long-term option was taking a job at another university. The Bully Extraordinaire remained in the department, creating a toxic environment anytime he did not get his way.

\section{Vignette \#5: Faculty to Staff (The Golden Haired Girl)}

She was the 'Golden Haired Girl' who charmed her superiors with her supposed intellect and resulting promise. It was, however, a time when universities were very much focused on affirmative action in hiring decisions. This had the effect of creating the perception of an unequal power balance wherein the Golden Haired Girl was considered untouchable. Unfortunately, she took this to heart in her research endeavors (or lack thereof), and in her dealings with departmental staff members. As her research efforts began to falter, she started blaming her shortcomings on the department's secretaries. She would verbally abuse them in public, and complain about their perceived incompetence to the department chair and anyone else who would listen. In effect, through her abuse, she created a toxic work environment whereby she attempted to shift the blame of her shortcomings from herself to others who could not fight back. Repeated interventions by the department chair were largely unsuccessful, due in part to the fact that the Golden Haired Girl was considered untouchable. One of the departmental secretaries eventually left the position because of the extreme hostilities. The other departmental secretary stayed because she 
needed the job. In the end, the Golden Haired Girl left the university for a job elsewhere, but not before inflicting severe psychological damage on both secretaries, and damaging the general collegiality in the department.

\section{Vignette \#6: Student to Faculty (The Group Bullies)}

She was a much respected faculty member known for her challenging and engaging classes. Her students were generally aware of her high standards, and many rose to the occasion. However, one semester, one of her more difficult classes was largely composed of cohort-based students who knew each other well both inside and outside of class. Several of the students had strong personalities and had been successful in the past in manipulating other class members to their points of view. In this particular class, the first two exams were rigorous, as they had been in past semesters. The class as a whole did not do as well as they thought they should. The strong personality students became Group Bullies, convincing their peers that the problem was not with their lack of mastery of the subject matter, but rather with the faculty member. The more the Group Bullies agitated their peers, the more hostile the situation became, quickly escalating into a group grievance against the faculty member. The grievance involved the department chair, the dean, and ultimately the provost. Largely because of the hostility that the Group Bullies were able to generate, the powers that be sided with the students. This was much to the dismay of the faculty member's departmental colleagues and the faculty member herself. She felt demeaned and betrayed, and passed away several years later carrying those feelings to her grave. Many of the students went on to graduate. Whether they were successful in their professional endeavors, however, is unknown.

\section{The Ultimate Dilemma}

Although the above vignettes reflect hypothetical situations, a common thread running through each is that those in administrative positions are indirectly or directly involved. This is likely to be the case in actual situations of bullying of educators by educators. The indirect administrative involvement manifests itself when the administrator is complicit by not taking appropriate steps to address and remedy complaints of and accusations of bullying. The other indirect involvement results when an administrator fails to ensure that meaningful policies are enforced to prevent the occurrence of bullying in the first place. These very points have been stressed by recent researchers in their investigation of bullying in higher education (e.g., Gray \& Gardiner, 2013; Lester, 2013).

The direct involvement where the administrator is the bully, is much more problematic for several reasons. First the administrator's bullying traits are generally deeply ingrained and reflective of mental health issues such as pathological narcissism and Machiavellianism (Piotrowski, 2015). Second, the more highly ranked the administrator, the less oversight will be applied to behavioral propensities. Third, the bully administrator will probably be unsympathetic to efforts aimed at addressing and/or curbing bullying activities and could impede any constructive steps in this direction. Fourth, the bully administrator probably would block any resultant investigations into inappropriate behavior. Finally, the bully administrator might retaliate against anyone who complained or supported the accuser, and hide behind a supposed superior administrative oversight (Kant et al., 2013).

\section{CONCLUSION}

Although strategies for dealing with adult bullies have appeared in the popular press (e.g., Elliott, 1997; Namie \& Namie, 2000), few proposals on effective interventions regarding adult bullying in higher education settings are evident in the research literature. In all situations, the best course of action is to avoid the bully. However, when confronted by a bully, stay calm, and recognize that personal confrontation is almost never productive. Submit corroborative evidence of incivility or incidents of bullying directly to the bully's immediate supervisor, and document any and all complaints. Chances are that the administrator has bullied more than one victim. Therefore, the more documentation, the more likely constructive actions can be implemented to thwart this toxic behavior. 

the academe:

The authors suggest the following initiatives that may ameliorate and manage incidents of adult bullying in

- Outline specific examples of behaviors, actions, and implications under the headings of Bullying/Incivility/Mobbing, etc., and promote written campus-wide policies on this destructive behavior for all levels of personnel. Such formal regulations should not only highlight the critical importance of this issue, but also prompt administrators to adhere to these campus-wide policies.

- All episodes of incivility and bullying should be taken seriously by academic administrators who should act expeditiously to intervene and resolve this behavior. Such prompt action conveys to all university personnel a high level of seriousness regarding matters concerning incivility and bullying.

- In addition to implementing a confidential hotline for reporting incidents of bullying, institutions of higher education should institute a panel consisting of university constituents to address, evaluate, and rule on bullying complaints. The ultimate goal is to make a concerted effort to designate the university as a 'No Bully Zone'.

\section{AUTHOR INFORMATION}

Chula King is a professor in the Department of Accounting and Finance at the University of West Florida. She earned her PhD from Louisiana State University and is a Certified Public Accountant in the State of Florida. She teaches in the areas of financial accounting and managerial accounting. Her primary research interest focuses on the impact of technology on higher education.

Chris Piotrowski has served as an independent educational consultant for the past 40 years. He has authored 250 publications, including 12 book chapters. In addition, Chris conducts research reviews for legal cases. Psychological testing, personality theory, bibliometrics, emergent pedagogical tools, and critique of research methodology are his major areas of scholarly interest. Chris has served as a reviewer for over 25 academic and professional journals.

\section{REFERENCES}

Blasé, J., \& Blasé, J. (2002). The dark side of leadership: Teacher perspectives of principal mistreatment. Educational Administration Quarterly, 38(5), 671-727.

Cassell, M.A. (2011). Bullying in academe: Prevalent, significant, and incessant. Contemporary Issues in Education Research, 4(5), 33-44.

Cemaloglu, N. (2011). Primary principals' leadership styles, school organizational health and workplace bullying. Journal of Educational Administration, 49(5), 495-512.

Elliott, M. (1997). 101 ways to deal with bullying. London: Hodden and Stoughton.

Fox, S., \& Stallworth, L.E. (2010). The battered apple: An application of stressor-emotion-control/support theory to teachers' experience of violence and bullying. Human Relations, 63(7), 927-954.

Frazier, K.N. (2011). Academic bullying: A barrier to tenure and promotion for African-American faculty. Florida Journal of Educational Administration and Policy, 5, 1-13.

Gray, N.L., \& Gardiner, M.E. (2013). Educator-peer workplace bullying: Why leadership must address incivility and create a quilt of caring in the school. Journal of School Leadership, 23, 823-845.

Kant, L., Skogstad, A., Torsheim, T., \& Einarsen, S. (2013). Beware the angry leader: Trait anger and trait anxiety as predictors of petty tyranny. Leadership Quarterly, 24, 106-124.

Keim, J., \& McDermott, J.C. (2010). Mobbing: Workplace violence in the academy. The Educational Forum, 74, 167-173.

Korkmaz, M., \& Cemaloglu, N. (2010). Relationship between organizational learning and workplace bullying in learning organizations. Educational Research Quarterly, 33(3), 3-38.

Lester, J. (Ed.). (2013). Workplace bullying in higher education. New York: Routledge.

Matsui, J. (2005). Bullying has serious consequences. Update, 33(5), 1-2.

Mourssi-Alfash, M. (2014). Workplace bullying and its influence on the perception of organizational justice and organizational citizenship behavior in higher education. Unpublished doctoral dissertation, Capella University. 
Namie, G., \& Namie, R. (2000). The bully at work. Naperville, IL: Sourcebooks, Inc.

Piotrowski, C. (2015). Adult Bully Syndrome: A bibliometric analysis on concordance with personality disorder traits. Journal of Instructional Psychology, 42(1), 1-3.

Randel, D. (2008). Attacking our educators. San Francisco: Xlibris Corp.

Raskauskas, J., \& Skrabec, C. (2011). Bullying and occupational stress in academia: Experiences of victims of workplace bullying in New Zealand universities. Journal of Intergroup Relations, 35(1), 18-36.

Sedivy-Benton, A., Strohschen, G., Cavazos, N., \& Boden-McGill, C. (2014). Good ol' boys, mean girls, and tyrants: A phenomenological study of the lived experiences and survival strategies of bullied women adult educators. Adult Learning, 26(1), 35-41.

Settles, I.H., \& O'Connor, R.C. (2014). Incivility at academic conferences: Gender differences and the mediating role of climate. Sex Roles, 71, 71-82.

Thomas, M. (2010). Perceptions of bullying in a higher education institution: A case study. Unpublished doctoral dissertation, University of Southampton, UK.

Thomas, M. (2005). Bullying among support staff in a higher education institution. Health Education, 105(4), 273288.

Twale, D.J., \& De Luca, B.M. (2008). Faculty incivility: The rise of the academic bully culture and what to do about it. San Francisco: Jossey-Bass. 